\title{
EGYPTIAN POTTERY FROM THE MIDDLE BRONZE AGE LEVANT IN CONTEXT
}

\author{
Chiara Pappalardo - University of Catania
}

The contribution aims at a reassessment of Egyptian and Egyptianizing pottery from stratified assemblages in the MBA Levant in light of the high chronology supported by the recent 'radiocarbon revolution'. The archaeological context of so-called 'key-types' that allowed previous cross-dates, together with the methods adopted for absolute dating, will be critically evaluated in order to avoid circular reasoning. The study will then attempt a regional synthesis integrating the examined artifacts with the radiocarbon chronology, the historical chronology of Egypt, and the relative sequence of cultural developments of the MBA Levant.

Keywords: Levant; Middle Bronze Age; chronology; Egyptian imports; pottery

\section{INTRODUCTION}

A coherent chronological framework is the sine qua non for the reconstruction of historical narratives. Several research projects have aimed at defining an interregional chronology of the first half of the second millennium BCE in Egypt and the Eastern Mediterranean based mainly on stylistic parallels from stratified assemblages of material culture, but while there is substantial agreement on regional relative sequences, absolute chronology is the subject of ongoing discussion. ${ }^{1}$ The beginning of this phase in the Levantine corridor (MB I, known previously as MB IIA) ${ }^{2}$ marked a major cultural unity of urban development. ${ }^{3}$ While a greater degree of continuity characterizes the urban centers of the so-called Northern Levant, ${ }^{4}$ a more integrated settlement system gradually emerged in the south through processes of societal reorganization and resilience, ${ }^{5}$ following a regional pattern that resulted in a dendritic system of centers with special social and economic functions related to their hinterlands. ${ }^{6}$ Settlement distribution along the major trade routes, together with textual and archaeological evidence, suggest that the network of international relationships played a paramount role in these developments. ${ }^{7} \mathrm{~A}$ 'low' (e.g., more recent) absolute chronology of these events has been suggested based on stratigraphic cross-dates between the site of Tell el-Dab'a, on the eastern Nile Delta, and key-sites of the SyroPalestinian area, ${ }^{8}$ shifting the transition from the MB I to the MB II and the subsequent MB III (previously known, respectively, as MB IIB and MB IIC), which saw the apex in terms

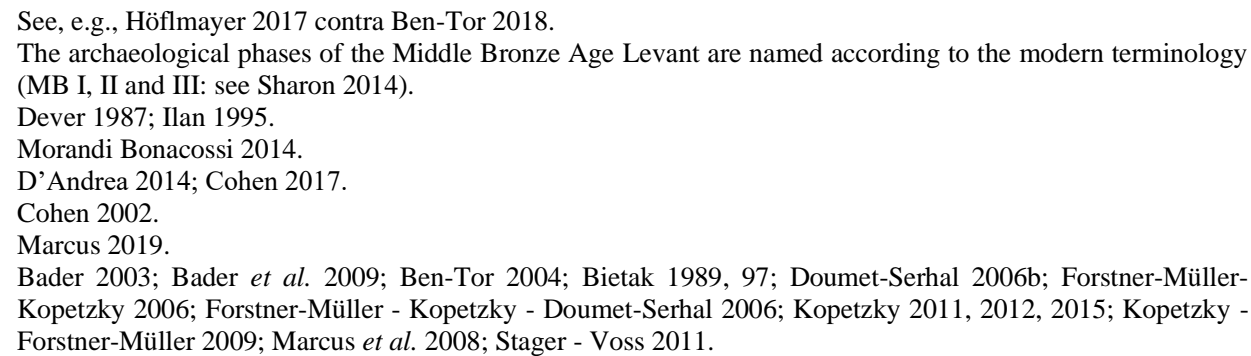


of size and number of fortified cities, ${ }^{9}$ of 90 to 120 years later than the traditional chronology. ${ }^{10}$ The supposed low chronology placed the end of the Middle Bronze Age between the early $18^{\text {th }}$ Dynasty and the Thutmosid period, hinting at a possible connection of the recurrent destructions of the final MB III with the military campaigns of the Thutmosid kings. ${ }^{11}$ In recent years, an independent, radiocarbon-backed 'high' (e.g., more ancient) chronology has challenged this picture, gaining support by ${ }^{14} \mathrm{C}$ dates from Tell elDab'a itself, with an offset 120 years ca. higher than the historical chronology. ${ }^{12}$ Radiocarbon dates modeled through a Bayesian probability approach, which agree substantially at a growing number of Levantine sites, ${ }^{13}$ seem to corroborate this evidence. The new data, coupled with comparative assessment of the material culture, indicate in fact a MB I/II transition around $1800 \mathrm{BCE}$, a MB II/III transition about $1700 \mathrm{BCE}$, and different regional trajectories of the $\mathrm{MB}$ III, which seems to draw to a close up to a century earlier in some settlements, before the start of the New Kingdom in Egypt. ${ }^{14}$

Egyptian specialized products imported in the Levant ${ }^{15}$ such as pottery, scarabs, sealings, and an extraordinary abundance of stone vessels, have long been regarded as anchors connecting the relative chronology of the Middle Bronze Age Levant to the political history of $\mathrm{Egypt}^{16}$. These classes of finds need to be reassessed in light of the 'radiocarbon revolution' that, with its unprecedented wealth of scientific data from both Egypt and the greater Levant ${ }^{17}$, is remodeling our perception of the cultural history of the Eastern Mediterranean and the Near East. In fact, a major argument supporting the low chronology is that radiocarbon dates are in gross conflict with the archaeological record, mainly represented by Egyptian seriation. ${ }^{18}$ To tackle this problem, the contribution will present the corpus of Egyptian and Egyptianizing pottery from the Levant ${ }^{19}$ following a regional perspective (fig. 1); find typological parallels to the discussed types, which have been redrawn in comparative tables (figs. 2, 3,4); and compare the time span of their

\footnotetext{
Burke 2008.

Bietak 2013. For the 'traditional' chronology, see Dever 1985, 1991.

For discussion, see Höflmayer 2019.

When using the high chronology of the Middle Kingdom: Kutschera et al. 2012.

Marcus 2003; Fall - Falconer - Höflmayer 2020; Höflmayer 2017; 2019; 2021.

Höflmayer et al. 2016a; 2016b; Höflmayer 2019; Fall - Falconer - Höflmayer 2020.

A major contribution on Egyptian evidence from the Levant in the MBA is in Mourad 2015, 147-185.

16 Helck 1971; Weinstein 1975; Bietak 1989, 97; Bader 2003; Ben-Tor - Ruhama 2004; Forstner-Müller Kopetzky - Doumet-Serhal 2006; Doumet-Serhal 2006b; Forstner-Müller - Kopetzky 2006; 2009; Marcus et al. 2008; Bader et al. 2009; Stager - Voss 2011; Kopetzky 2010-2011; 2011; 2012; 2015b.

17 Fall - Falconer - Höflmayer 2020; Höflmayer 2017; 2019; 2021; Kutschera et al. 2012; Mannings et al. 2014; Marcus 2003.

18 Especially with scarabs and clay seals attributed to the 13th Dynasty, and with the ceramic seriation from Tell el-Dab a: Bietak 2013; Ben-Tor 2018; Ben-Tor - Bell 2018; Bietak 2020.

19 Each vessel or sherd is briefly described with the nomenclature of Middle Kingdom shapes in Schiestl - Seiler 2012. For Marl C ceramics, B. Bader types (Bader 2001) are also included, and K. Kopetzky Formen (Kopetzky 2004; 2010) are reported for parallels from Tell el-Dab'a. For the ceramic fabric, I refer to the widely affirmed Vienna System (Nordstrom - Borriau 1993). An exception is the Marl DAN E3 fabric, which is not classified in the Vienna System: Seiler 2005, 35.
} 
circulation with the radiocarbon-backed chronology of the Levant ${ }^{20}$ and the historical chronology of Egypt. ${ }^{21}$ In order to avoid circular reasoning, we will look critically at the method used to date the context of the finds, and finally seek to integrate in a comprehensive synoptic table (tab. 1) the radiocarbon chronology with the historical chronology of Egypt and the relative, artifact-based chronology of the Levant.

\section{THE CORPUS OF EGYPTIAN POTTERY FROM THE LEVANT: AN OVERVIEW}

\subsection{The Southern Coastal Plain}

Egyptian pottery comes from the Middle Bronze Age strata in the North Slope of Ashkelon, ${ }^{22}$ where archaeology has uncovered a sequence of four gates and fortification systems with earthen freestanding ramparts and dry moats. ${ }^{23}$ The majority are Marl $\mathrm{C}^{24}$ closed vessels, more robust than the Nile clay types and particularly suitable to transportation, ${ }^{25}$ but there are also cooking pots, bowl rims, imitations ${ }^{26}$ and hybrid types. ${ }^{27}$ The repertoire falls within five phases (14-10) attributed to the MB I, II and III. ${ }^{28}$ Radiocarbon dates from phases 11 (1770-1683 cal. BCE, with an offset of roughly a century compared to the chronology based on the synchronization with dynastic Egypt through Tell el-Dab ${ }^{\prime}{ }^{29}{ }^{2}$ ) and 10 (1611-1453 cal. BCE), ${ }^{30}$ attributed respectively to the MB II and III, provide a terminus ante quem. The ashy layer of Moat $21,{ }^{31}$ contemporary with the first gate, provided the material to assess the absolute chronology of Ashkelon in the MB I, in particular more than forty clay seals and imported pottery wares that would make the phase broadly contemporaneous with the beginning of the $13^{\text {th }}$ Dynasty. ${ }^{32}$ From Phase 14 is the rim of a Marl C Egyptian zir ${ }^{33}$ corresponding to Bader type 5, found in Tell elDab'a strata G/4 and G/1-3. ${ }^{34}$ Similar shapes are known also from the West Block Refuse

20 The model proposed for this comparison is the one presented in Höflmayer 2017. The historical chronology of dynastic Egypt adopted for the comparison is the radiocarbon-backed model supporting the high Middle Kingdom chronology (Kitchen 2000; Bronk Ramsey et al. 2010; Bronk Ramsey - Shortland 2013).

21 The historical chronology of dynastic Egypt adopted for the comparison is the radiocarbon-backed model supporting the high Middle Kingdom chronology (Kitchen 2000; Bronk Ramsey et al. 2010; Bronk Ramsey Shortland 2013).

Stager - Voss 2011; Stager - Schloen - Voss 2018

Voss 2002; Stager et al. 2008; Stager - Schloen - Voss 2018.

Corresponding to fabric II-c at Tell el-Dab a: Czerny 1999, 47-50.

Marcus et al. 2008, 205.

Stager - Voss 2011, 124, pl. 2:4

See the Schalen mit rotem Kreuz in Stager - Voss 2011, 121-124.

Stager - Voss 2011.

Bietak et al. 2008.

Bruins - van der Plicht 2017.

1 Needs to recall here what has been noted by F. Höflmayer: «Although the context was published as being an 'ashy fill' of the moat (Stager et al. 2008, 224), in a recent paper it was claimed that 'the ash was an intentional lining of the sandstone moat"' and not a 'moat fill' (Stager - Voss 2011, 126, n.1). [...] It seems clear that the objects are in secondary or tertiary position and thus are not suitable for a detailed synchronization with finely stratified settlement material such as that from Tell el-Dab a» (Höflmayer 2015, 286). See also Cohen 2017, 36.

32 Bietak et al. 2008; Stager et al. 2008; Stager - Schloen - Voss 2018.

33 Stager - Voss 2011, 121, pl. 1:3.

34 E.g. Bader 2001, 167, fig. 48:d; 170, fig. 49:a. 
Deposit in Abydos-South ${ }^{35}$ and especially from a habitation layer at Lisht North, ${ }^{36}$ giving a chronology from the final Senwosret III to the $13^{\text {th }}$ Dynasty. Three sherds of Marl C store jar $^{37}$ (fig. 3:1) have been defined as Bader type 46, with corrugated neck and ovoid body. In Tell el- Dab'a the type seem to span from the second half of the $13^{\text {th }}$ Dynasty to the Second Intermediate Period. ${ }^{38}$ The body evolves from bag-shaped to ovoid, but since it is often missing, the classification is largely based on rims, and in particular on the uppermost horizontal groove, which tends to slide down in the most recent specimens. ${ }^{39}$ In such cases it is also virtually impossible to distinguish between this type and the previous type 47 , except maybe for a larger diameter of the last one..$^{40}$ If we take into account also the neck orientation, the examples quoted as parallels from Tell el- Dab'a look substantially more everted, almost funnel-like. The Ashkelon sherds have a neck visibly curved inward, maybe closer to an example from $12^{\text {th }}$ Dynasty Elephantine ${ }^{41}$ (fig. 3:4), to jars roughly dated to Senwosret I from Abu Ziyar, ${ }^{42}$ and examples from the ceramic complex 6 of the Pyramid of Amenemhet III at Dahshur ${ }^{43}$ (fig. 3:5). The sherds, consistent with the commingled nature of a fill, could thus have been in use already from Senwosret I and do not support a more accurate synchronization with the beginning of the $13^{\text {th }}$ Dynasty.

From a fill attributed to phase $13^{44}$ (end of the MB I-transitional MB I-II) is a sherd of a Marl C Egyptian $z i r^{45}$ described as Bader Type 4/5, but with a more elongated body. A piece of Bader type 46 Marl C store jar from the same phase is more everted than the previous ones ${ }^{46}$ (fig. 3:2). A similar example comes from the late $12^{\text {th }}-13^{\text {th }}$ Dynasty fortress at Askut $^{47}$ (fig. 3:6), so that for this type one could suggest either a regional or chronological difference. ${ }^{48}$ Nevertheless, comparisons of the Egyptian sherds do not support a fix date to the half of the $13^{\text {th }}$ Dynasty.

To phase 11, contemporary with Gate 4, belong the sherds of Egyptian zirs ${ }^{49}$ found in Street 90, leading from the Footgate to the house identified as the 'Sanctuary of the Silver Calf' ${ }^{50}$ These have been confronted by the excavators to Bader Type 7 series of water jars, for which a date to Hyksos period was proposed. The shape of the tall and everted rim, though, closely resembles the large Marl C jar or bottle from the Egyptian ceramic assemblage of the $13^{\text {th }}$ Dynasty habitation layer at Lisht North. ${ }^{51}$

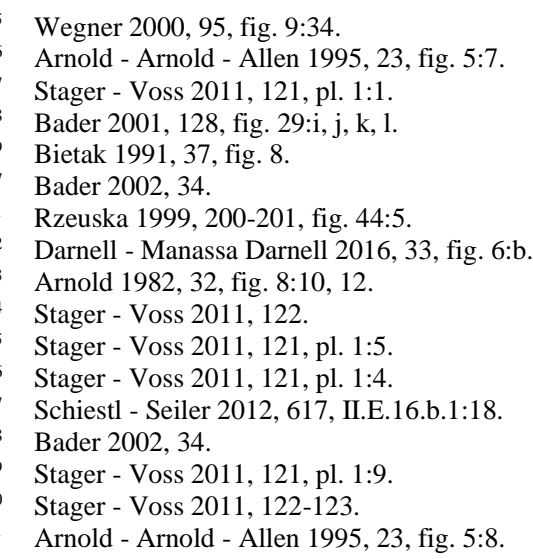


In phase 10 the Footgate with the corridor, the street and the Sanctuary of the Silver Calf were buried by rampart fills. ${ }^{52}$ The duration of this phase of the North Slope, although attributed by the excavator to the final MBA because of its association to Tell el- Dab 'a, seems uncertain for the long period of disuse and erosion before the construction of a new rampart in the Iron I. ${ }^{53}$ Notably, the rim of an Egyptian jar found on the summit of the Northern Slope has not been published for comparisons, but it was defined as a late Bader type $46,{ }^{54}$ reflecting either the prolonged diffusion of pottery that cannot be assumed as exact chronological indicators, or the extremely commingled nature of the fill layers in this part of the tell, with both residual and intrusive material.

Egyptian and Egyptianizing pottery from Tell el-'Ajjul has recently been examined by K. Kopetzky. ${ }^{55}$ The corpus comprises 79 shapes that her parallels with Tell el-Dab'a place especially at the beginning of the $18^{\text {th }}$ Dynasty ${ }^{56}$ as in the case of Petrie's type $31 \mathrm{Y} 20,{ }^{57}$ ovoid zirs with «out-turned, elongated and folded rims that were trimmed at the top». ${ }^{58}$ This consideration led the pottery expert to propose a dating for Palace I of Tell el-'Ajjul to the second half of the MB III. ${ }^{59}$ However, as noted by H. Winter, ${ }^{60}$ these finds lack reliable contextual information due to Petrie's pottery recording, so that the types cannot be adopted as secure indicators to date the different phases of the architectural complex at Tell el'Ajjul. Winter's reanalysis of Palace I within its broader regional context, instead, supports a late MB I date for this courtyard palace. ${ }^{61}$ Diagnostic sherds of Egyptian or Egyptian-style piriform jars and a shallow bowl have been identified in Trech 7 of the 1999-2000 joint Palestinian Swedish expedition. The sherds belong to three phases predating the Thera eruption, Horizon (H) 6, 7 and 8, that seem to fit within the cultural facies of the MB III. ${ }^{62}$ As the project has come to an abrupt halt, these finds have only generally been described as belonging to the Hyksos period, and to its first half in the case of a juglet in $\mathrm{H}_{8}{ }^{63}$

\subsection{The Sharon Plain}

At Tel Ifshar radiocarbon analyses have provided absolute dates for the transition between the MB I and the transitional MB I-II phase, which falls around the late $19^{\text {th }}$ or early $18^{\text {th }}$ century BCE. ${ }^{64}$ Egyptian imports, including zirs, globular jars and bottles, come from four successive general phases (A, B, C1 and C2) in the Area C Mittelsaalhaus complex. ${ }^{65}$ Since in-depth typological comparisons have been recently published, ${ }^{66}$ only

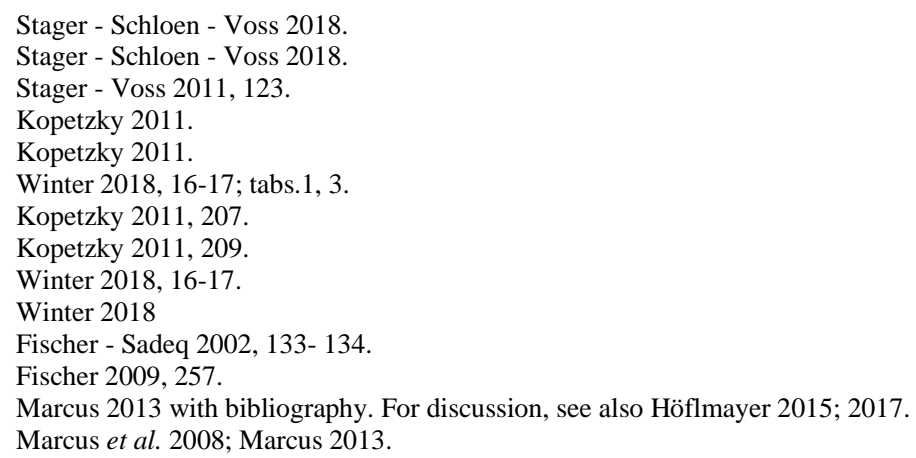


the types that we have not encountered yet will be recalled. To Phase A 'late' ${ }^{67}$ has been attributed a Marl A $4{ }^{68}$ sherd from below a floor. It was part of the rim and neck of a bottle ${ }^{69}$ with links to globular bottles with rounded base, and it has a parallel in an example from the cemetery of El-Kab (tomb 121), which was fine dated between the late Senwosret I and Senwosret III. ${ }^{70}$ Only to the general development between Senwosret I and Amenemhet III could be attributed the body of a small globular jar of sandy Marl C missing its upper part. ${ }^{71}$ To Phase B belong the sherds of an Egyptian globular jar of Marl DAN E3 fabric ${ }^{72}$ (fig. 4:1) with few close parallels in Egypt, all dating to the first half of the $12^{\text {th }}$ Dynasty, ${ }^{73}$ and a longer circulation in $\mathrm{Nubia}^{74}$ (fig. 4:3-5). From the same context are another small globular jar of Marl C2 fabric with a shorter neck ${ }^{75}$ and the fragments of a Marl C1 zir with bag-shaped body, flat base and squat rim of rounded triangular shape ${ }^{76}$ (fig. 2:1). The first, with the round and moderately elongated rim, has no exact parallels with a secure date, but its rim type appears from the reign of Amenemhet III to the early $13^{\text {th }}$ Dynasty in slightly larger examples. ${ }^{77}$ Zirs with squat rim of a rounded triangular shape seem to appear first in the second decade of the reign of Senwosret I and circulate until the first half of the $13^{\text {th }}$ Dynasty $^{78}$ (fig. 2:3-4). Parallels for this rim have been found also in the Western Nile Delta, in the late First Intermediate Period/early Middle Kingdom settlement of Abu Ghâlib ${ }^{79}$, where the rounded type and the more angular rim come from the same context. ${ }^{80}$ A duration of this settlement into the late $12^{\text {th }}$ Dynasty has been suggested by comparing the Marl $\mathrm{C}$ zirs from Trench A2 at the site with the material from Tell el-Dab ${ }^{\prime} a{ }^{81}$ but the examination of design seals from the excavation seemed to strongly support the previous, early dating. ${ }^{82}$ Recent stratigraphic analyses ${ }^{83}$ collocate within the destruction of the new building of Phase C a complete Egyptian bottle of Marl A3 fabric ${ }^{84}$ (fig. 4:2). The shape (round-based, ovoid and with a narrow neck) has been associated with a group of Upper Egyptian bottles whose time span is Amenemhet II - Senwosret III (fig. 4:6). Thus, the last year of this

6 Marcus et al. 2008.

Marcus 2013, 185.

Corresponding to fabric II-a at Tell el-Dab a: Czerny 1999, 47-50.

Marcus et al. 2008, 207, fig. 2:2.

Schiestl - Seiler 2012, 409, II.A.10:1.

Marcus et al. 2008, 207, fig. 2:3. For example of this type, see e.g., Arnold 1988, 134, fig. 74:183-184; Schiestl - Seiler 2012, 386, II.A.3.b.2:4.

Marcus et al. 2008, 207, fig. 3:1.

Schiestl - Seiler 2012, 397, II.A.7.b:1, 2

Schiestl - Seiler 2012, 397, II.A.7.b:3

Marcus et al. 2008, 208, fig. 3:2.

Marcus et al. 2008, 208, fig. 3:3.

Schiestl - Seiler 2012, 386, II.A.3.b; 397, II.A.7.b:2

Bader 2001, 16. For parallels, see Schiestl - Seiler 2012, 591, II.E.13.c:4; 595, II.E.13.d:10.

Bagh 2002, 61, fig. 10.

Trench A2: Bagh 2002, 39, 60-61.

Bagh 2002.

Bagh 2004; Ben-Tor - Ruhama 1998.

33 Marcus 2013.

84 Marcus et al. 2008, 211, fig. 2. 
pharaoh has been suggested as possible terminus ante quem for the phase. ${ }^{85}$ The decorative features on the bottle, consisting in clay rolls attached to the neck and lines incised on the shoulder, have a slightly wider chronology from the reign of Senwosret I to the $13^{\text {th }}$ Dynasty $^{86}$ (fig. 4:7).

\subsection{The Jezreel Valley}

From Beth Shean is a Marl A4 Egyptian squat jar ${ }^{87}$ or 'carinated vessel', ${ }^{88}$ red-slipped and polished. It was retrieved in Stratum R-3, ${ }^{89}$ dating to the final MB occupation phase, that is, according to the pottery examination conducted by A. Maeir, the final MB III. ${ }^{90}$ The vessel was found within a stone pit filled with dense ash and animal bones, together with a fragment of Chocolate-on-White ware. ${ }^{91}$ The shape is typical of Upper Egypt and quite rare in the Southern Levant. J. Borriau has suggested a date for the circulation of this form in Egypt from the late Second Intermediate Period to the early $18^{\text {th }}$ Dynasty. ${ }^{92}$

A large drop-shaped Egyptian-style jar from Tomb 3052, in Area BB of the Chicago Expedition at Megiddo, ${ }^{93}$ has been described as a clear example of Marl C zir. ${ }^{94}$ It belongs, according to the excavators, to Stratum X, corresponding to the Level J-13 of the Tel Aviv University excavation. ${ }^{95}$ The transition between this level and the following $\mathrm{J}-14$ seems to mark the change from the MB III to the LB I cultural horizon, although a certain difficulty in tracing this change is given by a major degree of continuity. ${ }^{96}$ In fact, this jar, together with an increasing number of gold objects in strata $X$ and IX, point towards the intensification of trade contacts with Egypt. ${ }^{97}$ The shape of the body, ovoid and with the maximum diameter in the medial third, together with the small base and the narrow mouth culminating in an upstanding rim with beveled lip, seem to indicate a type dating from the mid- $13^{\text {th }}$ Dynasty to the $15^{\text {th }}$ Dynasty. ${ }^{98}$

85 Marcus 2013.

86 De Garis Davies - Gardiner 1920, pl. XXXIX; Schiestl - Seiler 2012, 519, fig. II.D.a:2, 3, 4

87 Maeir 2007, pl. 27:13.

88 According to the typology from Holthoer 1977.

89 Mazar - Mullins 2007, 85-110.

90 Maeir 2007; 2010, 86-94. The publication of the site, in fact, follows the terminology that divides the Middle Bronze Age in MB IIA and MB IIB: Mazar - Mullins 2007, 12. K. Kopetzky has attributed the vessel to the MB II: Kopetzky 2015a, 313.

91 Mazar - Mullins 2007, 88-89.

92 Bourriau 1981, 30, 41; 1991, fig. 1.18:14, 18. For further discussions on the significance of this vessel, see Maeir 2007, 279-282; 2010, 48-50, 107-111, 128-129; Martin 2011, 66-69.

93 Loud 1948, pl. 43:4; Kempinski 1989, 142.

94 Arnold - Arnold - Allen 1995, 26, note 64, with references therein.

95 Finkelstein - Ussishkin - Cline 2013.

96 Adams - Bos 2013, 133-134.

97 Kempinski 1989.

98 Arnold - Arnold - Allen 1995, 23, fig. 5:6. 


\subsection{The coast of Lebanon}

Egyptian pottery, especially zirs for shipping commodities, has been identified at several sites on the Lebanese coast $^{99}$, notably at Sidon, Beirut, Byblos, FadousKfarabida, ${ }^{100}$ Tell Mirhan ${ }^{101}$, and Tell Arqa. ${ }^{102}$ Sidon yielded the largest assemblage of Egyptian pottery so far known from the Levant. ${ }^{103}$ These finds are from a cemetery area at the 'College Site', which has produced over a hundred Middle Bronze Age burials, spanning from the early MB I to the MB III and the early LBA. ${ }^{104}$ Most of the imports came from the cemetery surroundings, in all probability employed for ritual meals and feasting, ${ }^{105}$ while a few of them are from inside the tombs. ${ }^{106}$ Through the Egyptian imports in the tomb, and particularly scarab seriation, the excavator has attributed the Levels 1-3 to the MB I; Level 4 to the transitional MB I-II; Levels 5 and 6 to the MB II; and Levels 7 and 8 to the MB III. The repertoire of Egyptian pottery has been published so far mainly according to its fabric and typology, ${ }^{107}$ with little contextual indications. ${ }^{108}$ Storage facilities include zirs from Level 2, with 19 sherds of Egyptian fabric in Level 3, and over 50 Marl C sherds from Level 4. Nile clays appear, according to Kopetzky, at the very end of the MB III, ${ }^{109}$ and open shapes have also been presented from the site. ${ }^{110}$ From a burial in Level 1 was a Marl C globular jar with parallels from Senwoseret I to the late $12^{\text {th }}$ Dynasty. ${ }^{111}$ In Level 2, above an early MB I warrior burial, was a Marl A-2 burnished globular jar with everted rim. ${ }^{12}$ As seen above, upper Egyptian Marl jars seem restricted in Egypt to the first half of the $12^{\text {th }}$ Dynasty, while their longer circulation at Kerma ${ }^{113}$ could be seen as a sign of their enduring popularity. The repertoire of Marl C large-scale storage vessels is formed by globular, bag-shaped, and later ovoid zirs. ${ }^{114}$ These types have a long circulation with occasional overlapping, but we can say that the earlier type has parallels from mainly the $12^{\text {th }}$ Dynasty, ${ }^{115}$ while the second during the $13^{\text {th }}$ Dynasty ${ }^{116}$ (fig. 2:2). Similar to the older, globular zir is a storage vessel with trimmed rim and a spout, ${ }^{117}$ which

$99 \quad$ Kopetzky 2010-2011.

100 Kopetzky 2015a, 313 with bibliography.

101 Kopetzky et al. 2019.

102 Kopetzky 2015a, 313 with bibliography.

103 Bader 2003; Forstner-Müller - Kopetzky 2006; 2009; Forstner-Müller - Kopetzky - Doumet-Serhal 2006; Griffiths - Ownby 2006; Bader et al. 2009; Genz 2010-2011; Kopetzky 2011; 2012; 2015a.

104 Doumet-Serhal 2003; 2004a; 2004b; 2006a; 2009; 2012; 2016; Doumet-Serhal et al. 2014.

105 Doumet-Serhal 2010

106 Kopetzky 2012, 163.

107 Kopetzky 2012

108 Except for the sherds from Level 4 in Forstner-Müller - Kopetzky - Doumet-Serhal 2006.

109 Kopetzky 2012, 169, fig. 6:1-9.

110 Kopetzky 2012, 165, fig. 3:1-13

111 Doumet-Serhal 2003.

112 Kopetzky 2012, 164, fig. 2.

113 Rzeuska 2007, 415; Schiestl - Seiler 2012, 397, fig. II.A.7.b:3.

114 Kopetzky 2012, 166, fig. 4:9, 167, fig. 5:1-6.

115 E.g., Arnold 1988, 134, fig. 74:51; Schiestl - Seiler 2012, 591, II.E.13.c:4, 594, II.E.13.d:5, 595, II.E.13.d:10.

116 See the afore mentioned Egyptian zir from Megiddo and its parallels.

117 Kopetzky 2012, 167, fig. 5:7. 
has one of the earliest parallels at the cemetery of El-Lisht, ${ }^{118}$ in a deposit with material from especially the reigns of Senwosret III-Amenemhet III. ${ }^{119}$ The repertoire includes medium-sized jars, ${ }^{120}$ which are attested, with a progressive change in body shape from globular to bag-shaped, from post-Senwosret I to the first Hyksos period. ${ }^{121}$ Ovoid jars with corrugated neck at Sidon ${ }^{122}$ have also extraordinary large dimension, with mouth diameters above the usual 10 to 16 centimeters. These vessels are in fact particularly fitting to largescale trade, and in addition to the parallels found by Kopetzky in Tell el-Dab'a and Helwan ${ }^{123}$ one similar example comes from tomb 189 of the Kerma cemetery, dating to the Kerma Moyen IV (early - mid $12^{\text {th }}$ Dynasty). ${ }^{124}$ A rare piece is the rather small example of from a tomb attributed to the MB II. ${ }^{125}$ It seems a ceramic version of small calcite or gypsum ointment containers, the drop-shaped alabastra with ridged neck, which were widespread in funerary contexts of Egypt and the Levant from the $12^{\text {th }}$ Dynasty to the Second Intermediate Period, with a few examples surviving in the early $18^{\text {th }}$ Dynasty. ${ }^{126}$ An example from Kom Rabi'a ${ }^{127}$ level VIIb of the 'deliberate dump' (DD) in the RAT site has been attributed to the late $13^{\text {th }}$ Dynasty, although the case of intrusion and residuality in such a context, as clarified by the excavator, should not be ruled out. ${ }^{128}$

New evidence for Egyptian imports comes from Tell Fadous-Kfarabida, spanning from the EB I to the MB I (Phases I-VI). ${ }^{129}$ The Egyptian assemblage belongs to this last phase, represented on the top of the tell by three tombs, a few pits and surface finds. ${ }^{130}$ The chronology of Phase VI is based both on the material evidence, in particular the ceramic assemblage and a scarab from Tomb 736 attributed to the late $12^{\text {th }}-13^{\text {th }}$ Dynasty, ${ }^{131}$ and on a radiocarbon date from the same tomb, ${ }^{132}$ suggesting the late $19^{\text {th }}$-early $18^{\text {th }}$ century $\mathrm{BCE}$, which is in accordance with the scarab and should place the burial, following the radiocarbon-based chronology of dynastic Egypt, ${ }^{133}$ between Senwosret II and Sobekhotep II. ${ }^{134}$ A carinated bowl with a spout ${ }^{135}$ and a globular cooking pot ${ }^{136}$ have been found in two storage pits. ${ }^{137}$ Basins and bowls with a spout have a long tradition in Egypt and types close

118 Arnold 1988, 134, fig. 74:60.

119 Arnold 1988, 140-143.

120 Forstner-Müller - Kopetzky - Doumet-Serhal 2006, 52, fig. 2; Kopetzky 2012, 166, fig. 4:1-3.

121 Forstner-Müller - Kopetzky - Doumet-Serhal 2006, 52, fig. 2; Kopetzky 2012, 166-167 with bibliography.

122 Kopetzky 2012, 166, fig. 4:1-8.

123 Kopetzky 2012, 168 with bibliography.

124 Schiestl - Seiler 2012, 617, II.E.16.b.1:18.

125 Kopetzky 2012, 166, fig. 4:8.

126 Sparks 2007, 25-29.

127 Bourriau - Gallorini 2012, 129, fig. 25:63C2.1.

128 Bourriau - Gallorini 2012, 109.

129 Genz 2010-2011.

130 Genz et al. 2010a; 2010b.

131 Genz et al. 2010b, 265-266.

132 Genz et al. 2010b, 268.

133 Bronk Ramsey et al. 2010.

134 Genz et al. 2010b, 268.

135 Genz 2010-2011, 132, fig. 14:1.

136 Genz 2010-2011, 132, fig. 14:2.

137 Genz 2010-2011, 116 
to the afore mentioned example are attested from the late $12^{\text {th }}$ Dynasty. ${ }^{138}$ More fragments of an Egyptian zir from this area are mentioned in the reports. ${ }^{139}$

Two Egyptian jars have been published from Tell Arqa, in the 'Akkar plain. ${ }^{140}$ These were found in Level 13 of Area I. ${ }^{141}$ Radiocarbon dates place the transition to phase $\mathrm{N}$ of Level 13, the first of the MBA culture, around the $2000 \mathrm{BCE}$ ca., and the transition to phase $\mathrm{M}$, representing the culture of the MB II, ${ }^{142}$ within the date range $1850-1800$ BCE. ${ }^{143}$ One was a Marl C2 jar with corrugated neck, everted rim and a body reconstructed as slender and generally ovoid ${ }^{144}$ from a good local MB II context, for which parallels can be quoted from the ceramic complex 6 at Dahshur. ${ }^{145}$ Another Marl C jar comes from a leveling of an older phase not bounded to architectural features (fig. 3:3). It has a corrugated neck, a square rim folded on the outside and a groove at middle high of the neck ${ }^{146}$. A similar large jar with ovoid shape, tall neck and narrow mouth is from Lisht-North, ${ }^{147}$ where it seems to be a late Middle Kingdom precursor of a type that will become common in the New Kingdom. ${ }^{148}$

Exclusive relationships with Egypt were entertained by the courts of Byblos, Qatna and Ebla, as it is especially noticeable from the luxury Egyptian and Egyptian-style finds from the royal tombs. ${ }^{149}$ These prestigious items have been regarded as diplomatic gifts, but a different interpretation as products of Middle Kingdom tombs robbery during the Second Intermediate Period has been proposed within the frame of a recent re-dating of Byblos Royal Tombs. ${ }^{150}$ In particular, the synchronization of Tombs I and II with Tell el-Dab'a Phases E/3 and E/2 based on ceramic evidence from the two sites led to a collocation of these tombs within the MB II instead of the MB I, shifting consequently also the sequence of the other Gublite royal tombs. The tombs had been reopened in antiquity, so that with their chronological attribution one must tread carefully, but their relative chronology, that typical local pottery such as horizontally-combed dipper juglets places in the MB I, has also been correlated to the stratigraphy of Tell Mardikh by means of several comparable items. ${ }^{151}$ Golden bracelets with twisted wire, small stone unguentaria with horizontal rim, and the Orange Burnished Ware from the Tomb of the Princess at Ebla make the attribution of the Royal Tombs I and II at Byblos to the MB I cultural horizon, already suggested by

38 Arnold 1982, 32, fig. 8:1 and other parallels in Genz 2010-2011, 118.

139 Genz 2010-2011, 118

140 Thalmann 2006; Charaf 2009; Forstner-Müller - Kopetzky 2009.

141 Charaf 2009, 295.

142 MB II in current northern Levantine chronology.

143 Thalmann 2006

144 Charaf 2009, 296, pl. 2:5.

145 Arnold 1982, 32, fig. 8:8.

146 Charaf 2009, 296, pl. 2:6

147 Arnold - Arnold - Allen 1995, 23, fig. 5:9.

148 Arnold - Arnold - Allen 1995, 26.

149 See, e.g., Montet 1928; Scandone Matthiae 1979; 1987; 1997; Matthiae 1984; 1997; Matthiae - Pinnok Scandone Matthiae 1995; Matthiae et al. 2007; Nigro 2009; Pfälzner 2014; Kopetzky 2015b; 2016; 2018; Miniaci 2020.

150 Kopetzky 2015b; 2016; 2018; Miniaci 2020

151 Nigro 2009 
Gerstenblith, ${ }^{152}$ sound. Prestige items from the Northern Levant urban centers have also been recently framed within a convincing practice of reuse and imitation of imported goods from a 'globalized' system of exchange. ${ }^{153}$ Ceramic types such as the large jars for shipping commodities are not attributed to such a category of 'out-of-time' objects, and should therefore reflect broadly contemporary economic activities. A zir of the later ovoid type ${ }^{154}$ is likely to come from Tomb VI, ${ }^{155}$ whose relative chronology postdates Tombs I-IV ${ }^{156}$ and maybe Tomb VII. ${ }^{157}$ This piece is slightly later than the specimen from Megiddo, while its association with a probable piece of Chocolate-on-White ware recalls the MB III context of the Egyptian vase at Beth-Shean, ${ }^{158}$ so that the MB III horizon suggested by K. Kopetzky could fit the prolonged use of the Royal Tombs.

\section{CERAMIC 'KEY TYPES' AND RADIOCARBON DATES: FINAL CONSIDERATIONS}

A few vices in the operation of archaeological cross-dates need to be addressed here. The habit to infer the archaeological phase of strata or architectures in the Levant from the chronology attributed to a specific site, i.e., Tell el-Dab 'a, has been noticed several times. This praxis can be said to come from the often-biased association between archaeological facies and absolute dating, that is, between cultural phenomena and chronology. Instead, the two semantic domains should be kept well separated, as they pertain to two different questions we ask to the archaeological record: what and when. It is to avoid the recurrent confusion that the term 'cultural genome' has been recently proposed to indicate archaeological periods. ${ }^{159}$ Archaeological phases should ultimately refer to the sole relative chronology of a site, to its social, cultural and economic facts, which absolute dating methods collocate in time and history, but the other way around cannot be accepted. Secondly, the conventional association between material culture and regnant sequences requires major attention. Although typological seriation of stratified samples is an important step to establish a site relative chronology, changes in pottery shapes, especially when they do not involve substantial technological innovations, cannot be assumed as sharp chronological indicators. Concerning our case study, this is especially visible in the prolonged, and often overlapped, attestation of the marl $\mathrm{C}$ shapes for long distance trade with minor and gradual changes of the rim and body. The habit of a strict association between material culture and pharaohs regnal years should instead be integrated by other absolute dating methods, as the trajectory of cultural change has proved not to parallel the events of political history. ${ }^{160}$ One last problem concerns the context function of our findings, with special regard to domestic and funerary contexts. For tombs that are not clearly associated with contemporary settlement strata, or disturbed tombs as the Gublite

52 Gerstenblith 1983, 103

153 Miniaci 2020

154 Kopetzky 2016, 156, fig. 18: 3.

155 Kopetzky 2016, 155-156.

156 Nigro 2009, 165, tab. 2. For a different model, see Kopetzky 2016, 147, fig. 4, 148, fig. 5.

157 Kopetzky 2016, 154-155.

158 Kopetzky 2016, 155.

159 Nigro 2019. The contribution refers to the EBA Levant, but the methodological proposal is relevant here.

160 On this topic in the late MK and SIP, see especially Seiler 2005. 
ones, the attribution to specific cultural facies is quite problematic, ${ }^{161}$ and the association with chronological indicators such as scarabs can provide only a terminus post quem.

With these premises, some final considerations can be drawn through a synoptic table (tab. 1) where the ceramic 'key-types' seen above (bag-shaped and ovoid zirs, storage jars with corrugated neck from recurved to everted and with lowering first groove, globular bottles and carinated bowls) are distributed according to the time span of their circulation in Egypt outside the site of Tell el-Dab a. In order to allow a synthetic view, the table includes the absolute chronology emerging in the southern Levant, ${ }^{162}$ the historical chronology of Egypt, and the relative chronology of the Middle Bronze Age, together with the stratigraphic units of provenance of the vessels examined from the Levant. A reassessment of the Egyptian pottery from phases 14 and 13 of the ashy fill of Moat 21 at Ashkelon, that had been employed to synchronize the MB I horizon at the site with the $13^{\text {th }}$ Dynasty, has proven that in Egypt it was in circulation already at the time of the $12^{\text {th }}$ Dynasty and maybe as early as during the reign of Senwosret I. The parallels dating to the first half of the $12^{\text {th }}$ Dynasty that have been suggested for the fragmentary marl $\mathrm{C}$ store jars from the commingled assemblage of phase 14 are in accordance with the Egyptian synchronism advanced for the material from the MB I Mittelsaalhaus complex at Tel Ifshar (Phases A, $\mathrm{B}, \mathrm{C} 1$ and $\mathrm{C} 2$ ). The MB I cultural phase at the two sites of the southern Levant would thus align with the initial MBA at Sidon (Levels 1, 2 and 3) in the coastal Lebanon, while a slightly longer duration of the MB I horizon seems to emerge from the last phase at Tell Fadous-Kfarabida (Phase VI), although this is only attested in «surface contexts, a few pits, and three tombs». ${ }^{163}$ Notably, the finds examined from Tell Arqa suggest a synchronism of the MB II at the site (Phase M) with the second half of the $12^{\text {th }}$ Dynasty. The other site with Egyptian pottery from this phase is Ashkelon in the Southern Coastal Plain, where parallels from assemblages dated to the $13^{\text {th }}$ Dynasty have been advanced for the fragments of water jars from MB II layers (Phase 11). Although the largest assemblage of Egyptian pottery from the Levantine coast comes from Sidon, those finds cannot be considered here for the lack of contextual information relative to this phase, for which only a $13^{\text {th }}$ Dynasty parallel has been discussed. The integration of the aforementioned cross-dates to the radiocarbon chronology has a significant impact on the interpretation of Egyptian-Levantine interactions in the first two centuries of the $2^{\text {nd }}$ millennium BCE. In fact, it supports the synchronization of a transition to the MB II in the Levant with the middle of the $12^{\text {th }}$ Dynasty, contrary to the mid- $13^{\text {th }}$ Dynasty horizon suggested by the low chronology. The documentation of Egyptian pottery from different sites across the Levant in the MB I and the transitional MB I-II seems to reflect the wide range of the Egyptian economic interests in the Levant that is expressed especially in the Mit Rahina ${ }^{164}$ inscription and in the recently discovered fragments of inscription from the mastaba of Khnumhotep III in Dahshur. ${ }^{165}$ Since multiple lines of evidence suggest that Byblos was an important trading partner of Middle Kingdom

1 A different point of view is in Bietak 2020.

162 According to the scheme proposed in Höflmayer 2017.

163 Genz 2010-2011, 116

164 Marcus 2007.

165 Allen 2008 
Egypt, ${ }^{166}$ the lack of Egyptian pottery from the site in the MB I has been regarded as suspicious. ${ }^{167}$ However, this is not entirely the case if we look at the large jars for shipping commodities from the Royal Tombs as proxies that reflect ongoing economic activities, and thus maintain the attribution of the Gublite royal tombs I and II to the MB I cultural horizon. A high chronology of the MB I-II as supported by radiocarbon dates and archaeological cross-dates would also admit a 'maximalist' interpretation of the rich corpus of toponyms contained in the late Middle Kingdom Execration Texts, that would thus reflect not a distant memory of the Early Bronze Age city-states, as suggested by minimalist interpretations, but the historical reality of the fortified cities of MB II Palestine $^{168}$. Interesting information on the synchronization between Egypt and the MB III Levant emerge by crossing the data from the sites of Beth-Shean (Stratum R-3), Megiddo (Level J-13 / Stratum X), and Byblos (Tomb VI). The drop-shaped Marl C zir from the last MB III level at Megiddo has Egyptian parallels from the mid- $13^{\text {th }}$ to the $15^{\text {th }}$ Dynasty. ${ }^{169}$ For this reason, it has been described as a probable heirloom by the supporters of the low chronology, ${ }^{170}$ but the high chronology would allow for it to reflect broadly contemporary international trading activities. The Egyptian squat jar from a late MB III context at BethShean started circulating in Egypt during the late Second Intermediate Period, and the ovoid zir that is likely from the Royal Tomb VI at Byblos seems to have been produced between the late Second Intermediate Period and the early New Kingdom. ${ }^{171}$ Considering the different chronological length of the MB cultural horizon through the Levant, ${ }^{172}$ these data seem to fit the recently defined picture of an MB-LB transition that started to take place already during the Second Intermediate Period, while probably continuing into the Egyptian early New Kingdom. ${ }^{173}$ A first breakdown of the evidence therefore indicates that the integration of Egyptian and Egyptian-style pottery from the Levant with the radiocarbon and the political chronology can furnish additional support to the ongoing revision of the historical narrative in the light of the new, 'high' absolute dates.

\section{Catalogue}

4.1 Zirs (fig. 2)

2.1: Marl C1 rim and upper part of a large-scale storage jar (zir) with squat, roundedtriangular rim. From Tel Ifshar, Area C, Phase B (MB I) (Marcus et al. 2009, 208, fig. 3:3). 2.2: Marl C Egyptian ovoid zir. From Sidon, 'College Site' (MB II) (Kopetzky 2012, 167 fig. 5:4-5).

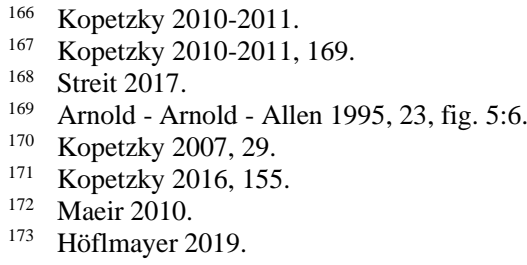


2.3: Marl C large storage jar with bag-shaped body and flat base. From Lisht, Pyramid complex of Senwosret I (southwall deposit I, second decade of Senwosret I) (Schiestl and Seiler 2012, 591, II.E.13.c:4).

2.4: Marl C large storage jar From Lisht, Pyramid complex of Senwosret I (early $12^{\text {th }}$ Dynasty) (Arnold 1988, 134, fig. 74:51).

2.5: Marl C zir with elongated rim and probably ovoid body. From Lisht - North, House A3.3, NK fill that had been taken from an existing late MK dump (13 ${ }^{\text {th }}$ Dynasty) (Arnold Arnold - Allen 1995, 23, fig. 5:5).

\subsection{Ridged-neck jars (fig. 3)}

3.1: Two sherds of Marl C1 Egyptian store jars with ridged, slightly recurved neck (Bader type 46). From Ashkelon, phase 14 (MB I) (Stager and Voss 2011, 121, pl. 1:1).

3.2: Sherd of a Marl C Egyptian store jar with ridged, everted neck (Bader type 46). From Ashkelon, phase 12, although maybe from phase 13 (transition from the MB I to the MB II) (Stager and Voss 2011, 121, pl. 1:4).

3.3: Marl C jar, probably medium-sized, with a square rim folded on the outside and a groove at middle high of the neck. From Tell 'Arqa, Phase N of Level 13 (MB I) (Charaf 2009, 301, pl. 2:6).

3.4: Marl C Egyptian store jar with ridged, slightly recurved neck. From Elephantine $\left(12^{\text {th }}\right.$ Dynasty) (Rzeuska 1999, 200-201, fig. 44:5).

3.5: Marl C Egyptian store jar with ridged neck (Bader type 46). From Dahshur, ceramic complex 6 of the pyramid of Amenemhet III (1825 - 1760 BCE) (Arnold 1982, 32, fig. 8:10).

3.6: Marl C Egyptian store jar with ridged neck (Bader type 46). Found at Askut, fortress (from the late $12^{\text {th }}$ to the $13^{\text {th }}$ Dynasty) (Schiestl and Seiler 2012, 616, fig. II.E.16.b.1:13). 3.7: Marl C jar with two grooves on the corrugated, everted neck. From Lisht - North, House A3.3, NK fill that had been taken from an existing late MK dump (13 ${ }^{\text {th }}$ Dynasty) (Arnold - Arnold - Allen 1995, 23, fig. 5:8).

\subsection{Globular jars and bottles (fig. 4)}

4.1: Rim, base and body of a Marl DAN E3 globular jar with short, slightly everted neck and triangular-shaped modelled rim. From Tel Ifshar, area C, Phase B (MB I) (Marcus et al. 2009, 208, fig. 3:1).

4.2: Marl A3 ovoid bottle with clay rolls attached on the long neck and incised lines on the shoulder. From Tel Ifshar, area C, Phase C2 (MB I) (Marcus et al. 2009, 211, fig. 4:2).

4.3: Marl A4 globular jar with short, everted neck and triangular-shaped modelled rim. From at Dra' Abu el-Naga, Area H, tomb K03 (possibly first half of the $12^{\text {th }}$ Dynasty) (Schiestl and Seiler 2012, 397, fig. II.A.7.b:1).

4.4: Marl A4 globular jar with short, everted neck and triangular-shaped modelled rim. From El-Kab, Middle Kingdom Cemetery, tomb 34 (mid-12 $2^{\text {th }}$ Dynasty) (Schiestl and Seiler 2012, 397, fig. II.A.7.b:2).

4.5: Marl A2 globular jar with short, everted neck and triangular-shaped modelled rim. From Kerma, cemetery sector CE 14, tomb 22 (mid-12 $2^{\text {th }}$ e early $13^{\text {th }}$ Dynasty) (Schiestl and Seiler 2012, 397, fig. II.A.7.b:3). 
4.6: Marl DAN E3 ovoid bottle, with clay rolls attached on the long neck and incised lines on the shoulder. From El-Kab, Middle Kingdom Cemetery, tomb 84 (Amenemhet II Senwosret III) (Schiestl and Seiler 2012, 519, fig. II.D.a:1).

4.7: Neck of a Marl A bottle with clay rolls. From Askut fortress (late $12^{\text {th }}-13^{\text {th }}$ Dynasty) (Schiestl and Seiler 2012, 519, fig. II.D.a:3).

\section{REFERENCES}

ALLEN, J.P.

2009 The Historical Inscription of Khnumhotep at Dahshur: Preliminary Report: Bulletin of the American Schools of Oriental Research 352 (2009), pp. 29-39.

ADAMS, M.J. - Bos, J.M.

2013 Part IV: Sub-Area Upper J: I. FinkeLsTein - D. Ussishrin - E.H. Cline (eds.), Megiddo V: the 2004-2008 seasons (Sonia and Marco Nadler Institute of Archaeology. Monograph Series 31), Winona Lake 2013, pp. 119-142.

ARNOLD, D.

1982 Keramikbearbeitung in Dahschur 1976 - 1981: Mitteilungen des Deutschen Archäologischen Instituts abteilung Kairo 38 (1982), pp. 25-65.

19881988 The Pyramid of Senwosret I (Publications of the Metropolitan Museum of Art. Egyptian Expedition XXV), New York 1988.

ARnold, D. - ARnold, F. - Allen, S.

1995 Canaanite imports at Lisht, the Middle Kingdom capital of Egypt: Egypt and the Levant 5 (1995), pp. 13-32.

BADER, B.

2001 Tell el-Dab 'a XIII. Typologie und Chronologie der Mergel C-Keramik (Untersuchungen der Zweigstelle Kairo des Österreichischen Archäologischen Instituts 19), Wien 2001.

2002 A Concise Guide to Marl C Pottery: Egypt and the Levant 12 (2002), pp. 29-54.

2003 The Egyptian jars from Sidon in their Egyptian context: Archaeology and History in the Lebanon 18 (2003), pp. 31-37.

BAder, B. - Forstner-Müller, I. - KoPetzky, K. - Doumet-Serhal, C.

2009 An Egyptian jar from Sidon in its Egyptian context. Some fresh evidence: Archaeology and History in the Lebanon 29 (2009), pp. 79-83.

BAGH, T.

2002 Abu Ghâlib, an Early Middle Kingdom Town in the Western Nile Delta: Renewed Work on Material Excavated in the 1930s: Mitteilungen des Deutschen Archäologischen Instituts abteilung Kairo 58 (2002), pp. 29-61.

2004 Early Middle Kingdom Seals and Sealings from Abu Ghâlib in the Western Nile Delta Observations: M. BIETAK - E. CZERNY (eds.), Scarabs of the Second Millennium BC from Egypt, Nubia, Crete and the Levant: Chronological and Historical Implications BEN-TOR, D (Contributions to the Chronology of the Eastern Mediterranean 8), Wien 2004, pp. 13-25.

2018 Evidence for Middle Bronze Age Chronology and Synchronisms in the Levant: A Response to Höflmayer et al.: Bulletin of the American Schools of Oriental Research 379 (2018), pp. 43-54. 
BEN-TOR, D. - BELL, L.

2018 Clay Sealings from the Moat Deposit: L.E. STAGER - J.D. SCHLOEN - R.J. Voss (eds.), Ashkelon 6: The Middle Bronze Age Ramparts and Gates of the North Slope and Later Fortifications, Winona Lake 2018, pp. 337-381.

BEN-TOR, A. - RUHAMA, B.

1998 The Absolute Date of the Montet Jar Scarabs: L.H. LeSKo (ed.), Ancient Egyptian and Mediterranean Studies in Memory of William A. Ward, Providence 1998, pp. 1-17.

2004 Hazor and Chronology: Egypt and the Levant 14 (2004), pp. 45-67.

BIETAK, M.

1989 The Middle Bronze Age of the Levant - A New Approach to Relative and Absolute Chronology: P. ÅstRöm (ed.), High, Middle or Low? Acts of an International Colloquium on Absolute Chronology Held at the University of Gothenburg 20th-22nd August 1987: Part 3 (Studies in Mediterranean Archaeology and Literature Pocket-book 80), Stockholm 1989, pp. 78-120.

1991 Egypt and Canaan during the Middle Bronze Age: Bulletin of the American Schools of Oriental Research 282 (1991), pp. 28-72.

2002 The Middle Bronze Age in the Levant: Proceedings of an International Conference on MB IIA Ceramic Material, Vienna, 24th-26th of January 2001 (Contributions to the Chronology of the Eastern Mediterranean 3), Wien 2002.

2013 Antagonism in Historical and Radiocarbon Chronology: C. BRONK RAMSEY - A.J. SHORTLAND (eds.), Radiocarbon and the Chronologies of Ancient Egypt, Oxford 2013, pp. 76-109.

2020 Why Radiocarbon Dates from Egyptian Funerary Contexts are Approximately Accurate while those from Stratified Settlements are Precisely Wrong: J. KAMRIN - M. BÁRTA - S. IKram - M. LehNeR - M. Megahed (eds.), Guardian of Ancient Egypt: Studies in Honor of Zahi Hawass, Vol. I, Prague 2020, pp. 235-245.

BieTAK, M. - Kopetzky, K. - StAGer, R.L. - Voss, R.

2008 Synchronisations of Stratigraphies: Ashkelon and Tell el-Dab'a: Egypt and the Levant 18 (2008), pp. 49-60.

BOURRIAU, J.D.

1981 Nubians in Egypt during the Second Intermediate Period: An Interpretation based on the Egyptian Ceramic Evidence: D. ARNOLD (hrsg.), Studien zur altägyptischen Keramik, (Sonderschriften des Deutschen Archäologischen Institut, Kairo 9) Mainz 1981, pp. 2541.

1991 Relations between Egypt and Kerma during the Middle and New Kingdoms: W.V. DAviES (ed.), Egypt and Africa. Nubia from Prehistory to Islam, London 1991, pp. 129144.

BOURRIAU, J.D. - GALLORINI, C.

2012 Memphis: Pottery from Memphis, Kom Rabi'a: R. SCHIESTL - A. SeILER (eds.) Handbook of the Pottery of the Egyptian Middle Kingdom, vol. 2: The Regional Volume (Contributions to the Chronology of the Eastern Mediterranean 28), Wien 2012, pp. 107130

Bronk Ramsey, C. - Rowland, J. - Dee, M.W. - Higham, T.F.G.

2010 Radiocarbon-Based Chronology for Dynastic Egypt: Science 328 (2010), pp. 1554-1557

Bronk Ramsey, C. - ShortLand, A.J.

2013 Radiocarbon and the Chronologies of Ancient Egypt, Oxford 2013. 
BRUINS, H.J. - VAN DER Plicht, J.

2017 The Minoan Santorini Eruption and its ${ }^{14} \mathrm{C}$ Position in Archaeological Strata: Preliminary Comparison Between Ashkelon and Tell el-Dab'a: Radiocarbon $59 / 5$ (2017), pp. 12951307.

BURKE, A.A.

2008 Walled Up to Heaven: The Evolution of Middle Bronze Age Fortification Strategies in the Levant (Studies in the Archaeology and History of the Levant 4), Leiden 2008.

CHARAF, $\mathrm{H}$.

2009 Arqa and its regional connections redux: A.M. MAÏLA-AFEICHE (ed.), Interconnections in the Eastern Mediterranean: Lebanon in the Bronze and Iron Ages. Proceedings of the International Symposium Beirut 2008 (Bulletin d'Archéologie et d'Architecture Libanaises, Hors-Série VI), Beirut 2009, pp. 295-309.

2014 The Northern Levant (Lebanon) During the Middle Bronze Age: A.E. KILLEBREw - M. STEINER (eds.), The Oxford Handbook of the Archaeology of the Levant: c. 8000-332 $B C E$, Oxford 2014, pp. 434-450.

COHEN, S.L.

2002 Canaanites, chronologies and connections: the relationship of Middle Bronze IIA Canaan to Middle Kingdom Egypt (Studies in the Archaeology and History of the Levant 4), Winona Lake 2002.

2017 Reevaluation of Connections between Egypt and the Southern Levant in the Middle Bronze Age in Light of the Recent Higher Chronology: Journal of Egyptian Interconnections 13 (2017), pp. 34-42.

CZERNY, E.

1999 Tell el-Dab'a IX (Untersuchungen der Zweigstelle Kairo des Österreichischen Archäologischen Instituts 15), Wien 1999.

D'ANDREA, M

2014 The Southern Levant in Early Bronze IV: Issues and Perspectives in the Pottery Evidence, 2 vols. (Contributi e Materiali di Archeologia Orientale 17), Rome 2014.

DARnell, J.C. - Manassa DaRnell, C.

2016 Umm-Mawagir in Kharga Oasis: an Industrial Landscape of the Late Middle Kingdom/Second Intermediate Period: G. MinIACI (ed.), The World of Middle Kingdom Egypt (2000-1550 BC). Contributions on archaeology, art, religion, and written sources, Vol. II (Middle Kingdom Studies 2), London 2016, pp. 27-70.

DE GARIS DAVIES, N. - GARDINER, A.

1920 The Tomb of Antefoker, Vizier of Sesostris I, and of his Wife, Senet (The Theban tombs series), London 1920.

DOUMET-SERHAL, C.

2003 Weapons from the Middle Bronze Age Burials at Sidon: Archaeology and History in the Lebanon 18 (2003), pp. 30-57.

2004a Sidon (Lebanon): Twenty Middle Bronze Age Burials from the 2001 Season of Excavation: Levant 36 (2004), pp. 89-154.

2004b Sixth and Seventh Seasons of Excavation at Sidon. Preliminary Report: Bulletin d'Archéologie et d'Architecture Libanaises 8 (2004), pp. 47-82.

2006a Eighth and Ninth Seasons of Excavation at Sidon: Bulletin d'Archéologie et d'Architecture Libanaises 10 (2006), pp. 131-165.

2006b Sidon: Mediterranean Contacts in the Early and Middle Bronze Age, Preliminary Report: Archaeology and History in the Lebanon 24 (2006), pp. 34-37.

2009 Tenth, Eleventh and Twelfth Seasons of Excavation (2008-2010) at Sidon: Bulletin d'Archéologie et d'Architecture Libanaises 13 (2009), pp. 7-54. 
2010 Sidon during the Bronze Age: Burials, Rituals and Feasting Grounds at the 'College Site': Near Eastern Archaeology 73 (2010), pp. 114-129.

2012 Mortuary Practices in Sidon in the Middle Bronze Age: A Reflection on Sidonian Society in the Second Millennium BC: P. PfäLzNER - H. NIER - E. PernickA - S. LANGE - T. KÖSTER (eds.), Contextualising grave inventories in the Ancient Near East. Proceedings of a workshop at the London 7th ICAANE in April 2010 and an International Symposium in Tübingen in November 2010, both organised by the Tübingen Post-Graduate School "Symbols of the Dead", Wiesbaden 2012, pp. 29-37.

2016 Sidon: The 2013 and 2014 Seasons of Excavation, and 16 Years on College Site: Berytus LVI (2016), pp. 87-130.

DOUMET-SERHAL, C. - Boschloos, V. - Williams, M. - Bordreuil, P.

2014 Thirteenth and fourteenth season of excavation (2011-2012) at Sidon: preliminary Report: Bulletin d'Archéologie et d'Architecture Libanaises 15 (2014), pp.175-238.

DEVER, W.G.

1987 The Middle Bronze Age: the Zenith of the Urban Canaanite Era: The Biblical Archaeologist 50 (1987), pp. 148-177.

FALL, P.L. - FALCONER, S.E. - HÖFLMAYER, F.

2020 New Bayesian Radiocarbon Models and Ceramic Chronologies for Early Bronze IV Tell Abu En-Ni'aj and Middle Bronze Age Tell El-Hayyat, Jordan: Radiocarbon 63/1(2020), pp.41-76.

FinKelstein, I. - USSISHKIN, D. - CLINE, E.H.

2013 Megiddo V: The 2004-2008 Season (Sonia and Marco Nadler Institute of Archaeology. Monograph Series 31), Winona Lake 2013.

FISCHER, P.M.

2009 The chronology of Tell el- Ajjul, Gaza: Stratigraphy, Thera, Pumice and Radiocarbon: D.A. Warburton (ed.), Times Up! Dating the Minoan Eruption of Santorini. Acts of the Minoan Eruption Chronology Workshop, Sandbjerg November 2007 (Monographs of the Danish Institute at Athens 10), Aarhus 2009, pp. 253-265.

FISCHER, P.M. - SADEQ, M.

2002 Tell el- Ajjul 2000: Second Season Preliminary Report: Egypt and the Levant 12 (2002), pp. 109-153.

FORSTNER-MÜLLER, I. - KOPETZKY, K.

2006 An Upper Egyptian import at Sidon: Archaeology and History in the Lebanon 24 (2006), pp. 60-62.

2009 Egypt and Lebanon: New Evidence for Cultural Exchanges in the first half of the 2nd Millennium. B.C: A.M. MAÏLA-AFEICHE (ed.), Interconnections in the Eastern Mediterranean: Lebanon in the Bronze and Iron Ages: Proceedings of the International Symposium Beirut 2008 (Bulletin d'Archéologie et d'Architecture Libanaises, Hors-Série VI), Beirut 2009, pp. 143-157.

ForstNer-Müller, I. - KoPETZKy, K. - Doumet-SERHAL, C.

2006 Egyptian pottery from the late 12th and 13th dynasty from Sidon: Archaeology and

GENZ, H. History in the Lebanon 24 (2006), pp. 52-59.

2010-2011 Middle Bronze Age Pottery from Tell Fadous-Kfarabida, Lebanon: Berytus 53-54 (20102011), pp. 115-132.

GenZ, H. - El-ZAATARI, S - ÇAKIRlAR, C. - BAdREShANi, K. - Riehl, S.

2010 A Middle Bronze Age burial from Tell Fadous-Kfarabida, Lebanon: Egypt and the Levant 20 (2010), pp. 183-205. 
Genz, H. - Daniel, R - Damick, A. - Ahrens, A. - El-ZaAtari, S - Höflmayer, F. - Kutschera, W. WILD, E.M.

2010 Excavations at Tell Fadous-Kfarabida: Preliminary report on the 2010 season of excavations: Bulletin d'Archéologie et d'Architecture Libanaises 14 (2010), pp. 241-274. GerstenBlith, P.

1983 The Levant at the Beginning of the Middle Bronze Age (American Schools of Oriental Research Dissertation Series 5), Winona Lake 1983.

GRIFFITHS, D. - OwNBY, M.

2006 Assessing the occurrence of Egyptian Marl C ceramics in Middle Bronze Age Sidon: HELCK, W. Archaeology and History in the Lebanon 24 (2006), pp. 63-77.

1971 Die Beziehungen Ägyptens zu Vorderasien im 3. und 2. Jahrtausend v. Chr. (Ägyptologischen Abhandlungen 5), Wiesbaden 1971.

HOLTHOER, R

1977 New Kingdom Pharaonic Sites: The Pottery: The Scandinavian Joint Expedition to Sudanese Nubia 5/1, Lund 1977.

HÖFLMAYER, F.

2015 Carbone-14 Comparé: Middle Bronze Age I (IIA) Chronology, Tell el-Dab'a and Radiocarbon Data: J. MYNÁŘovÁ - P. ONDERKA - P. PAVúK (eds.), There and Back Again The Crossroads II, Prague 2015, pp. 265-295.

2017 A Radiocarbon Chronology for the Middle Bronze Age Southern Levant: Journal of Ancient Egyptian Interconnections 13 (2017), pp. 20-33.

2019 The Expulsion of the Hyksos and the End of the Middle Bronze Age: a Reassessment in light of Recent Chronological Research: Journal of Ancient Egyptian Interconnections 21 (2019), pp. 20-30.

2021 Tel Nami, Cyprus, and Egypt: Radiocarbon Dates and Early Middle Bronze Age Chronology: Palestine Exploration Quarterly, https://doi.org/10.1080/00310328.2020.1866329.

Höflmayer, F. - Kamlah, J. - SADER, H. - Dee, M.W. - Kutschera, W. - WiLd, E.M. - Riehl, S.

2016b New Evidence for Middle Bronze Age chronology and synchronisms in the Levant: radiocarbon dates from Tell el-Burak, Tell el-Dab'a, and Tel Ifshar Compared: Bulletin of the American School of Oriental Research 375 (2016), pp. 53-76.

Höflmayer, F. - YAsur-Landau, A. - Cline, E.H. - Dee, M.W. - LoRentzen, B. - Riehl, S.

2016a New Radiocarbon dates from Tel Kabri support a high Middle Bronze Age chronology: Radiocarbon 58/3 (2016), pp. 599-613.

ILAN, D.

1995 The Dawn of Internationalism - The Middle Bronze Age: T.E. LEvy (ed.) The KEMPINSKI, A Archaeology of Society in the Holy Land, London 1995, pp. 297-319.

1989 Megiddo. A City-State and Royal Centre in North Israel (Materialien zur Allgemeinen und Vergleichenden Archäologie 40), München 1989.

KITCHEN, K.A.

2000 Regnal and Genealogical Data of Ancient Egypt (Absolute chronology I): The Historical Chronology of Ancient Egypt, a Current Assessment: M. BIETAK (ed.), The Synchronization of Civilisations in the Eastern Mediterranean in the Second Millennium B.C. (Contributions to the Chronology of the Eastern Mediterranean 1), Wien 2000, pp. $39-52$. 
KOPETZKY, K.

2004 Typologische Bemerkungen zur Siedlungskeramik von A/V - p/19: H. HEIN - P. JÀNOSI (eds.), Tell el-Dab'a XI. Areal A/, Siedlungsrelikte der späten 2. Zwischenzeit (Untersuchungen der Zweigstelle Kairo des Österreichischen Archäologischen Instituts 21), Wien 2004, pp. 237-335.

2010 Tell el-Dab 'a XX. Die Chronologie der Siedlungskeramik der Zweiten Zwischenzeit aus Tell el-Dab'a (Untersuchungen der Zweigstelle Kairo des Österreichischen Archäologischen Instituts 32), Wien 2010.

2010-2011 Egyptian pottery from the Middle Bronze Age in Lebanon: Berytus 53-54 (2010-2011), pp. 167-180.

2011 The Southern Coastal Plain: Tell el-Ajjul: M. MARTIN (ed.), Egyptian-Type Pottery in the Late Bronze Age Southern Levant, (Contributions to the Chronology of the Eastern Mediterranean 29), Wien 2011, pp. 201-209.

2012 The Egyptian corpus of the Middle Bronze Age layers of Sidon: Archaeology \& History in the Lebanon 34-35 (2012), pp. 163-172.

2015a Imports and Local Pottery Production in Egypt and the Levant during the Middle Bronze Age: Bulletin de Liaison du Groupe International d'Étude de la Céramique Égyptienne 25 (2015), pp. 309-321.

2015b Egyptian Burial customs in the Royal tombs I - III of Byblos: Bulletin d'Archéologie et d'Architecture Libanaises Hors-Série X (2015), pp. 393-412.

2016 Some Remarks on the Relations between Egypt and the Levant during the late Middle Kingdom and Second Intermediate Period: G. MiniACI (ed.), The World of Middle Kingdom Egypt (2000-1550 BC). Contributions on archaeology, art, religion, and written sources, Vol. II (Middle Kingdom Studies 2), London 2016, pp. 143-159.

2018 Tell el-Dab a and Byblos: New Chronological Evidence: Egypt and the Levant XXVIII (2018), pp. 309-358.

Kopetzky, K. - Genz, H. - Schwall, C. - Rom, J. - HAas, F. - Stark, M. - Dremel, F. - Börner, M.

2019 Between Land and Sea: Tell Mirhan and the Chekka Regional Survey: Preliminary report of the survey and first excavation season (2016-2018): Egypt and the Levant XXIX (2019), pp. 105-124.

Kutschera, W. - Bietak, M. - Wild, E.M. - Bronk Ramsey, C. - Dee, M.W. - Golser, R. Kopetzky, K. - Stadler, P. - Steiner, P. - Thanheiser, U. - Weinger, F.

2012 The Chronology of Tell el-Dab'a: A Crucial Meeting Point of 14C Dating, Archaeology, and Egyptology in the 2nd Millennium BC: Radiocarbon 54 (3-4) (2012), pp. 407-422.

Loud, G.

1948 Megiddo II. Seasons of 1935 - 39: text and plates (Oriental Institute Publications 62), MAEIR, A.M. Chicago 1948.

2007 The Middle Bronze Age II Pottery: A. MAZAR - R. Mullins (eds.), Excavations at Tel Beth-Shean 1989-1996, Volume II: The Middle and Late Bronze Age Strata in Area R, Jerusalem 2007, pp. 279-282.

2010 In the Midst of the Jordan. The Jordan Valley during the Middle Bronze Age (circa 20001500 B.C.E). Archaeological and Historical Correlates (Contributions to the Chronology of the Eastern Mediterranean 26), Wien 2010.

Mannings, S.W. - Höflmayer, F. - Moeller, N. - Dee, M.W. - Bronk Ramsey, C. - Fleitmann, D. HigHAM, T.F.G. - KUTSCHERA, W. - WILD, E.M.

2014 Dating the Thera (Santorini) Eruption: Coherent Archaeological and Scientific Evidence Supporting a High Chronology: Antiquity 88 (2014), pp. 1164-1179. 
MARCUS, E.S.

2003 Dating the Early Middle Bronze Age in the southern Levant: a preliminary comparison of radiocarbon and archaeo-historical synchronizations: M. BIETAK (ed.), The Synchronisation of Civilisations in the Eastern Mediterranean in the Second Millennium B.C. II (Contributions to the Chronology of the Eastern Mediterranean 4), Vienna 2003, pp. $95-110$.

2007 Amenemhet II and the Sea: Maritime Aspects of the Mit Rahina (Memphis) Inscription: Ägypten und Levante 17 (2007), pp. 137-90.

2013 Correlating and Combining Egyptian Historical and Southern Levantine Radiocarbon Chronologies at Middle Bronze Age IIa Tel Ifshar, Israel: A.J. SHortland - C. Bronk RAMSEY (eds.), Radiocarbon and the Chronology of Ancient Egypt, Oxford 2013, pp. 182208.

2019 A Maritime Approach to Exploring the Hyksos Phenomenon: M. BIETAK - S. Prell (eds.), The Enigma of the Hyksos Volume 1 (Contributions to the Archaeology of Egypt, Nubia and the Levant 9), Wiesbaden 2019, pp. 149-164.

Marcus, E.S - Porath, Y. - Schiestl, R. - Seiler, A. - Paley, S.M.

2008 The Middle Kingdom Egyptian Pottery from Middle Bronze Age IIA Tell Ifshar: Egypt and the Levant 18 (2008), pp. 203-219.

MARTin, M. (ed.)

2011 Egyptian-type Pottery in the Late Bronze Age Southern Levant (Contributions to the Chronology of the Eastern Mediterranean 29), Wien 2011.

MatThiae, $\mathrm{P}$.

1984 I tesori di Ebla, Roma - Bari 1984.

19971997 Ebla and Syria in the Middle Bronze Age: E.D. OREN (ed.), The Hyksos: New Historical and Archaeological Perspectives (University Museum Monographs 96; Museum symposium series 8), Philadelphia 1997, pp. 379-414.

Matthiae, P. - Nigro, L. - Peyronel, L. - Pinnock, F.

2007 Proceedings of the International Colloquium 'From Relative Chronology to Absolute Chronology: The Second Millennium BC in Syria-Palestine' (Rome 29th November - 1st December 2001) (Contributi del Centro linceo interdisciplinare Beniamino Segre 117), Roma 2007.

Matthiae, P. - Pinnock, F. - Scandone Matthiae, G.

1995 Ebla. Alle origini della civiltà urbana. Trent'anni di scavi in Siria dell'Università di Roma "La Sapienza", Milano 1995.

MAZAR, A. - Mullins, R. (eds.)

2007 Excavations at Tel Beth-Shean 1989-1996, Volume II: The Middle and Late Bronze Age Strata in Area R, Jerusalem 2007.

MiNIACI, G.

2020 At the dawn of the Late Bronze Age "globalization": the (re)-circulation of Egyptian artefacts in Nubia and the Northern Levant in the MB II-mid MB III (c. 1710 - 1550 BC): Claroscuro 19/1 (2020), pp. 1-26.

MONTET, P.

1928 Byblos et l'Égypte: Quatre Campagnes de Fouilles à Gebeil, 1921-1924, Paris 1928.

MORANDI BONACOSSI, D.

2014 The Northern Levant (Syria) during the Middle Bronze Age: A.E. KiLlebrew - M. STEINER (eds.), The Oxford Handbook of the Archaeology of the Levant (c. 8000-332 $B C E$ ), Oxford 2014, pp. 408-427. 
MOURAD, A.L.

2015 Rise of the Hyksos: Egypt and the Levant from the Middle Kingdom to the Early Second NIGRO, L. Intermediate Period (Archaeopress Egyptology 11), Oxford 2015.

2009 The Eighteen Century BC Princes of Byblos and Ebla and the Chronology of the Middle Bronze Age: Bulletin d'Archéologie et d'Architecture Libanaises VI (2009), pp. 159-175.

2019 Archaeological periodization vs absolute chronology: what does not work with high and low Early Bronze Age in the Southern Levant: E. Gallo (ed.), Conceptualizing Human Experiences: Tell es-Sultan and Tall al-Hammām, Early Bronze cities across the Jordan (Rome «La Sapienza» Studies on the Archaeology of Palestine \& Transjordan 13), Roma 2019, pp. 1-46.

NORDSTROM, H.A. - BOURRIAU, J.

1993 Ceramic technology: clays and fabrics: D. ARNOLD - J. BouRriau (eds.), An introduction to Ancient Egyptian Pottery (Sonderschrift des Deutsches Archäologisches Institut. Kairo 17/1), Mainz 1993, pp. 147-190.

PFÄLZNER, P.

2014 Royal Funerary Practices and Inter-regional Contacts in the Middle Bronze Age Levant: New Evidence from Qatna: P. PfÄLzNER - H. NIER - E. PERNICKA - S. LANGE - T. KöSTER (eds.), Contextualising grave inventories in the Ancient Near East. Proceedings of a workshop at the London 7th ICAANE in April 2010 and an International Symposium in Tübingen in November 2010, both organised by the Tübingen Post-Graduate School "Symbols of the Dead" (Qatna-Studien Supplementa 3), Wiesbaden 2014, pp. 141-156. RZEUSKA, T.I.

1999 Zur Keramik des Mittleren Reiches: Mitteilungen des Deutschen Archäologischen Instituts abteilung Kairo 55 (1999), pp. 195-204.

2007 Egyptian pots from El-Gamamiya: Polish Archaeology in the Mediterranean 19 (2007), pp. 415-419.

SCANDONE MATTHIAE, G.

1979 Un oggetto faraonico della XIII dinastia dalla 'Tomba del Signore dei Capridi': Studi eblaiti 1 (1979), pp. 119-128.

1987 The Mace of Pharaoh Hotepibra and the Connections between Egypt and Syria-Palestine in the XIIIth Dynasty: S. ShaATs (ed.), Studies in the History and Archaeology of Palestine: Proceedings of the First International Symposium on Palestine Antiquity, Vol. 2, Aleppo 1987, pp. 49-58.

1997 The Relations between Ebla and Egypt: E.D. OREN (ed.), The Hyksos: New Historical and Archaeological Perspectives, Philadelphia 1997 (University Museum Monographs 96; Museum symposium series 8), pp. 415-427.

SCHIESTL, R. - SeILER, A. (eds.)

2012 Handbook of Pottery of the Egyptian Middle Kingdom (Contributions to the Chronology SEILER, A. of the Eastern Mediterranean 28), Wien 2012.

2005 Tradition und Wandel. Die Keramik als Spiegel der Kulturentwicklung Thebens in der Zweiten Zwischenzeit, Mainz 2005.

SHARON, I.

2014 Levantine Chronology: M.L. STEINER - A.E. KILLEBREW (eds.), The Oxford Handbook of the Archaeology of the Levant, c. 8000 - 332 BCE, Oxford 2014, pp. 44-65.

SPARKS, R.T.

2007 Stone vessels in the Levant (Palestine Exploration Fund Annuals VIII), Maney 2007. 
Stager, L.E. - Schloen, J.D. - Master, D.M. - Press, M.D. - AJA, A.

2008 The North Slope: L.E. StAGER - J.D SChloen - D.M MASTER (eds.), Ashkelon 1: Introduction and Overview (1985-2006), Winona Lake 2008.

STAGER, L.E. - SCHLOEN, J.D - Voss, R.J.

2018 Ashkelon 6: The Middle Bronze Age Ramparts and Gates of the North Slope and Later Fortifications, Winona Lake 2018.

STAGER, L.E. - Voss, R.J.

2011 Egyptian Pottery in Middle Bronze Age Ashkelon: Eretz - Israel 30 (2011), pp. 119-126.

STREIT, K.

2017 A Maximalist Interpretation of the Execration Texts - Archaeological and Historical Implications of a High Chronology: Journal of Ancient Egyptian Interconnections 13 (2017), pp. 59-69.

THALMANN, $\mathrm{P}$

2006 Tell Arqa - I. Les niveaux de l'âge du Bronze (Bibliothèque archéologique et historique Voss, R.J. 177), Beyrouth 2006

2002

A Sequence of Four Middle Bronze Age Gates in Ashkelon: M. BIETAK (ed.), The Middle Bronze Age in the Levant, Proceedings of an International Conference on MB IIA Ceramic Material (Vienna 2001) (Contributions to the Chronology of the Eastern WEGNER, J. Mediterranean 3), Wien 2002, pp. 379-384.

2000 The Organization of the Temple Nfr-K3 of Senwosret III at Abydos: Egypt and the Levant X (2000), pp. 83-125.

WEINSTEIN, J.

1975 Egyptian Relations with Palestine in the Middle Kingdom: Bulletin of the American Schools of Oriental Research 217 (1975), pp. 1-16.

WINTER, H.A.

2018 Tell el-`Ajjul palaces I and II: Context and function: Palestine Exploration Quarterly 150 (1) (2018), pp. 4-33. 


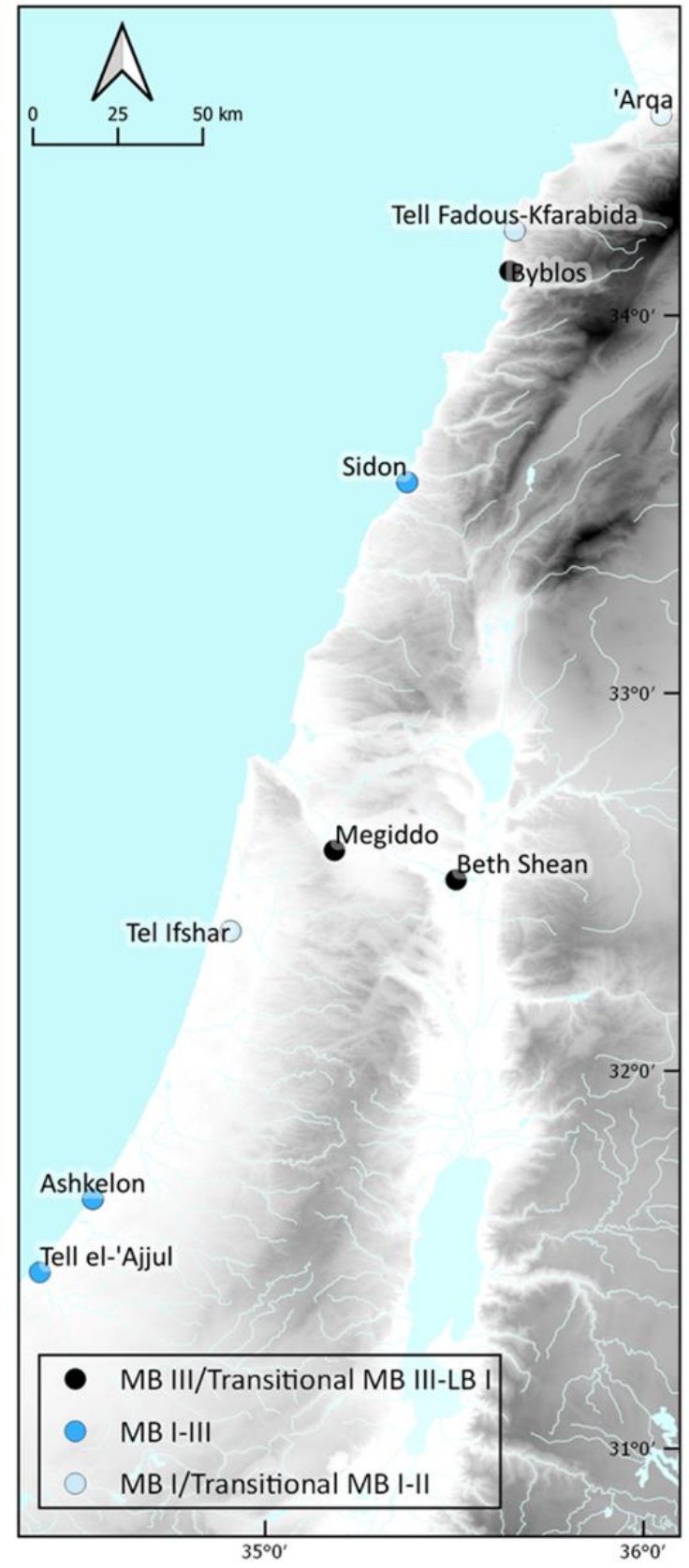

Fig. 1 - Egyptian and Egyptianizing pottery from the Levant mentioned in the text. 


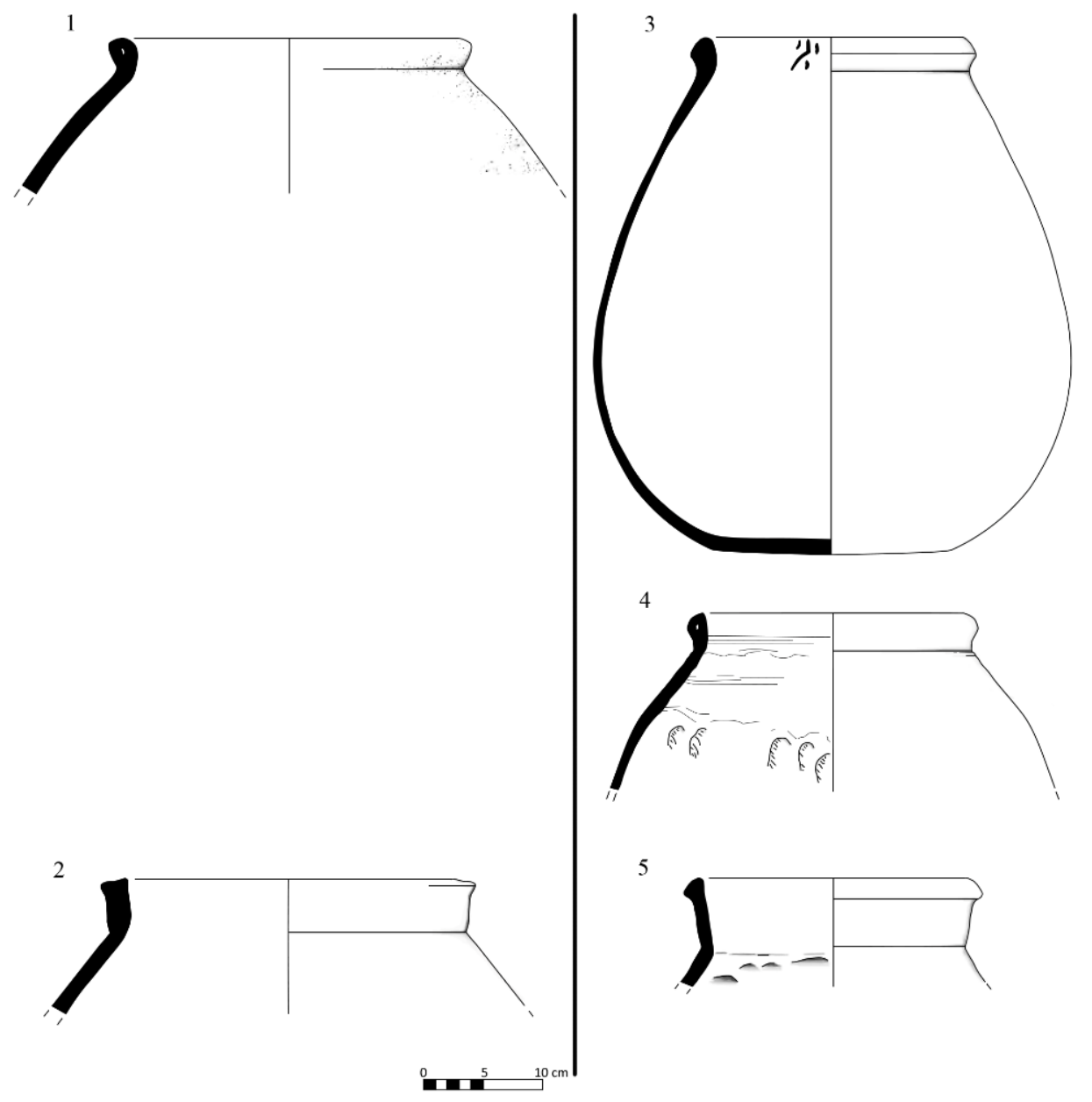

Fig. 2 - Egyptian zir from the Levant (left) with parallels from Egypt (right). 


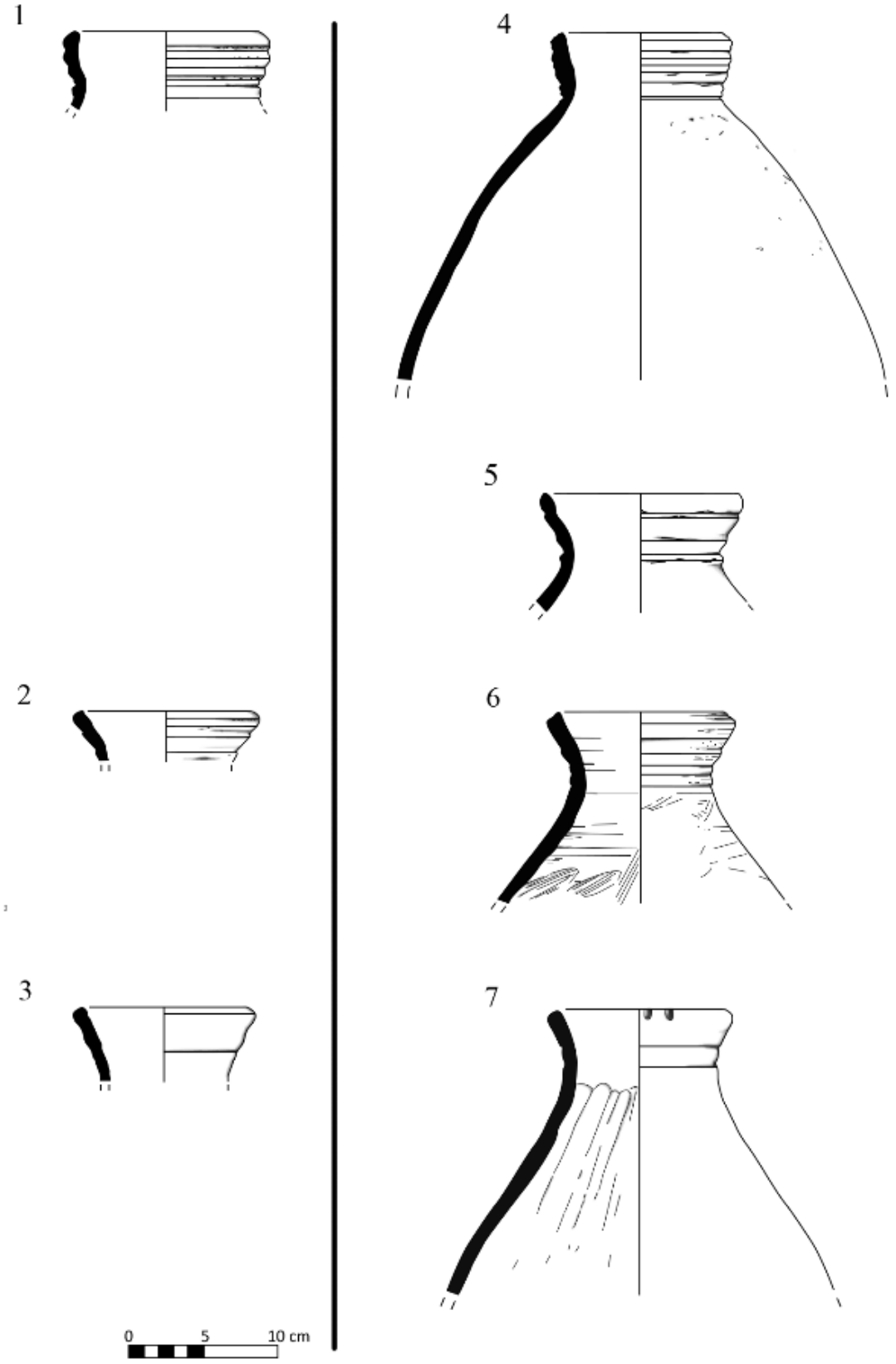

Fig. 3 - Egyptian ridged-neck jars from the Levant (left) with parallels from Egypt (right). 


$$
1
$$

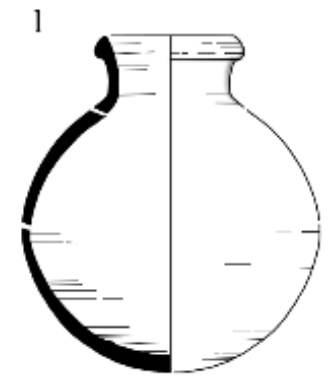

2

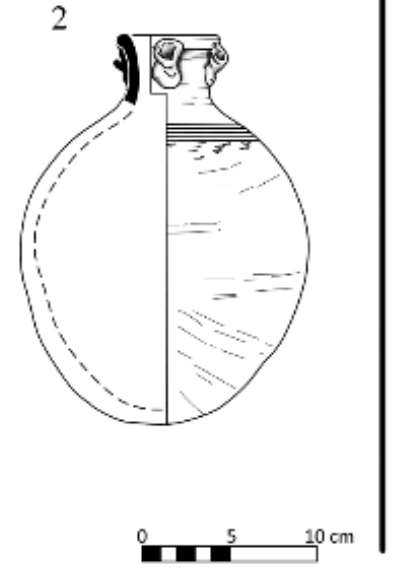

3

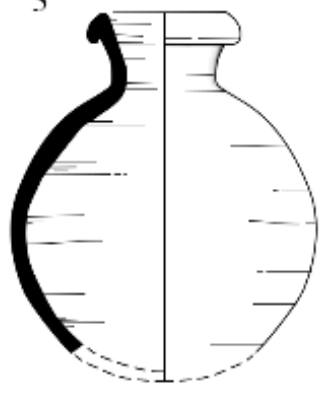

5

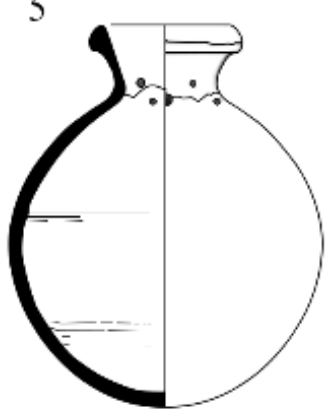

6

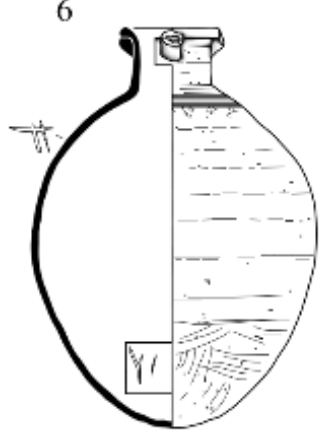

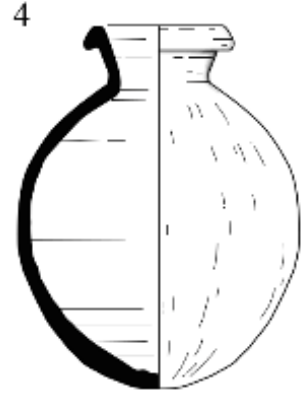

7

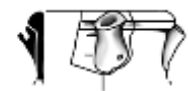

Fig. 4 - Egyptian globular jars and bottles from the Levant (left) with parallels from Egypt (right). 


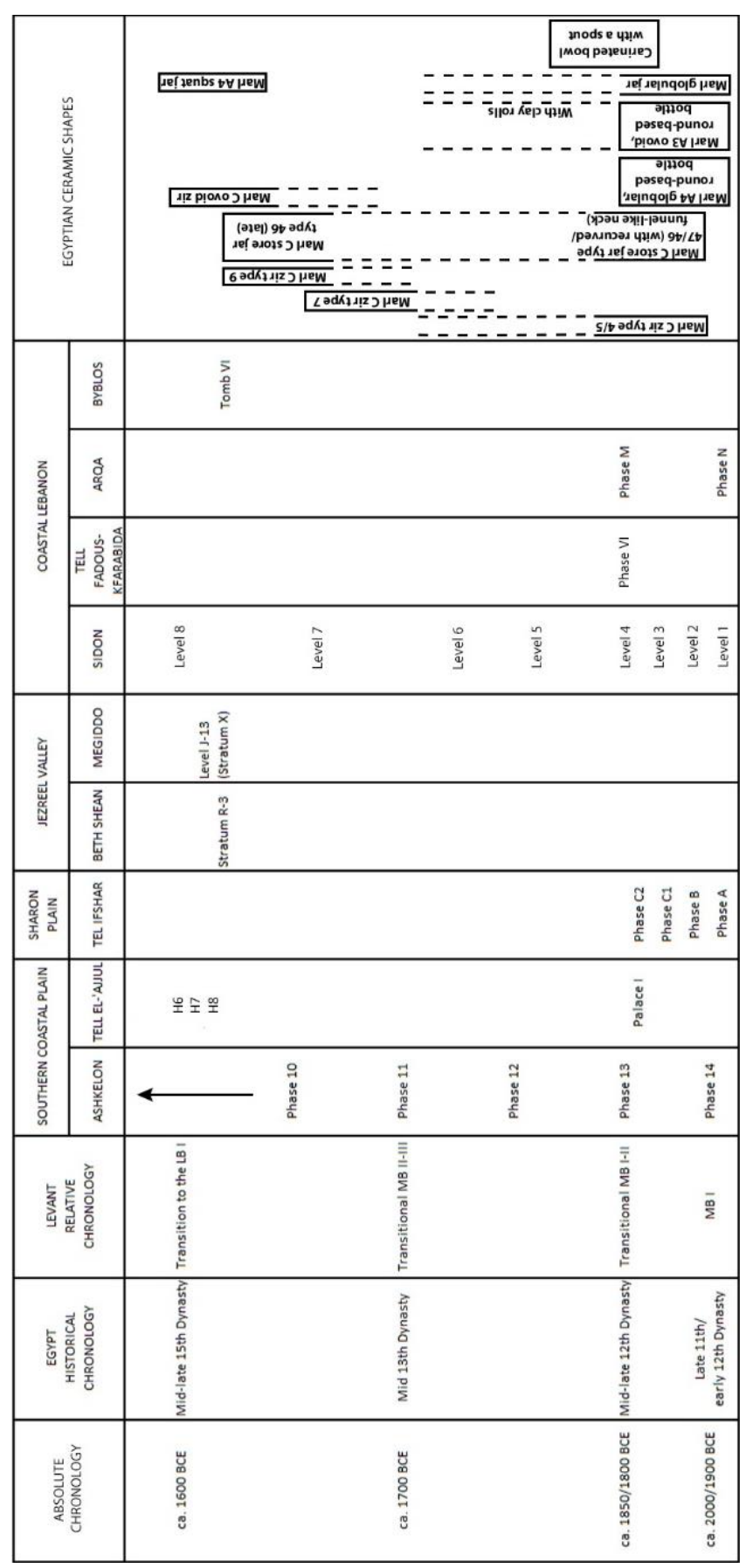

